\title{
医用インプラント材原料によるラットの皮膚および 筋組織におけるフリーラジカルの発生に関する研究
}

岡山大学医学部附属分子細胞医学研究施設神経情報学部門（指導：森 昭片教授）

遠藤 由 美

(平成 7 年 2 月 14 日受稿)

Key words：フリーラジカル, 筋組織, 皮眉組織, 医用インプラント材原料, ラット

緒

\section{言}

最近の種々の人工臟器材料の開発と普及に伴 い, 生体反応のより少をい医用インプラント材 の開発が要求されている。.また他面，人工関節 などの場合には素材の摩隇による微粒子と生体 組織との反応も重要な研究課題となっている. これらの医用インプラント材のうち，ネジやプ レートには金属が使用され，また人工䁍器など に金属の合金が主成分として使用されている. しかし，過剩量の遷移金属は生体内においては 毒性を示すことが知られている．例えばクロム

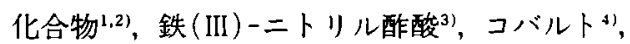
ニッケル5.6)などは活性酸素種生成と DNA 損傷 をおこすことが見い出され，発癌性金属とされ ている，また，銅，鉄およU゙マンガンは過酸化 水素または発癌物質と反応して活性酸素種を生 成し，DNA 損傷をおこすことが示されている7-9?.

本研究においてはラットの皮膚および筋組織 内へ種々の実用化されている医用インプラント 材原料のペレットを埋め込み，生体膜に毒性の 強いヒドロキシルラジカル $(\cdot \mathrm{OH})$ と、さらに ・OHによって生ずる生体膜由来のカーボンセン ターラジカル $(\cdot \mathrm{C})$ の発生について電子スピン 共鳴 (electron spin resonance, ESR) スペク トロメーターを用いて検討した。

\section{材料と方 法}

\section{1. 試薬}

スピントラップ凮の5,5-dimethyl-1pyrroline-N-oxide (DMPO) は第一化学薬品工
業株式会社（東京）より購入した。その他の試 薬は市販の最高純度のものを使用した。

\section{2. 実験動物}

生後 8〜9週撂の雄性 Wistar ラットをCharles River Japan Inc. より購入して使用した。 実験動物は12時間明暗サイクル(午前 7 時より 午後 7 時までを明期）のもとで飼育し，飼料は オリエンタル醉母工業株式会社製の標準飼料 MF を使用した，水は給水瓶で自由に捸水させ た。

3. 医用インプラント材原料

京セラ株式会社より供与されたアルミナ $\mathrm{Al}_{2}$ $\mathrm{O}_{3}$ (純度 $99.5 \%$ 以上，粒子サイズ $63 \sim 90 \mu \mathrm{m}$ ), ジルコニア $\mathrm{ZrO}_{2}(63 \sim 90 \mu \mathrm{m})$, チタン(純チ夕 ン, $45 \mu \mathrm{m}$ 以下)，コバルトークロム合金（コバ ルト 7〜30\%，モリブデン 5〜 7\%，53〜250 $\mu \mathrm{m}$ ), 超高分子ポリエチレン (Trace Element (Al, Ti, Ca, Cl)の合計は620pm以下, $250 \mu \mathrm{m}$ 以下）のペレットを用いた。これらの材料のぺ レット各100mgはペントバルビタール麻酔下にラ ットの腹部皮唐組織（皮下組織を含む）と大腿 部筋粗織内に埋め込んだ。

4.試料の採取

上記ペレットを埋め込んだ後，1，3，20時 間， 2 および 4 週間目にラットを断頭し，埋め 込み部分の皮虐およU゙皮下組織ならびに筋組織 を摘出後，分析開始まで液体窒素中に保存した。 次いで摘出した組織に20倍量の生理食塩水を加 えてホモゲナイズし，ホモジネート0.2mlにスピ

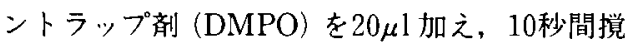
抖後, ESR スペクトロメーター(JEOL JES.FE1 
Table 1 Free radical levels in the skin and muscle of sham-operated rats.

\begin{tabular}{|c|c|c|c|c|c|}
\hline \multirow{2}{*}{$\begin{array}{l}\text { Free radicals } \\
\left(\times 10^{14} \text { spins } / \mathrm{ml}\right)\end{array}$} & 1 & 3 & 20 & 2 & 4 \\
\hline & \multicolumn{3}{|c|}{ hours } & \multicolumn{2}{|c|}{ weeks } \\
\hline \multicolumn{6}{|l|}{ skin } \\
\hline Hydroxyl radical & $\begin{array}{c}4.05 \pm 2.18 \\
(5)\end{array}$ & $\begin{array}{c}8.93 \pm 2.38 \\
(5)\end{array}$ & $12.4 \pm 2.30$ & $5.05 \pm 0.53$ & $\begin{array}{c}3.72 \pm 2.20 \\
(4)\end{array}$ \\
\hline Carbon centered radical & $\begin{array}{c}3.06 \pm 0.44 \\
(4)\end{array}$ & $\begin{array}{c}3.59 \pm 2.34 \\
(6)\end{array}$ & $\frac{8.41 \pm 3.78}{(3)}$ & $\begin{array}{c}3.70 \pm 2.00 \\
(4)\end{array}$ & $1.45 \pm 0.63$ \\
\hline \multicolumn{6}{|l|}{ muscle } \\
\hline Hydroxyl radical & $4.62 \pm 1.06$ & $5.89 \pm 0.82$ & $\begin{array}{c}8.53 \pm 2.92 \\
(4)\end{array}$ & $5.21 \pm 1 \pm 1.57$ & $\begin{array}{c}5.89 \pm 2.72 \\
(4)\end{array}$ \\
\hline Carbon centered radical & $\begin{array}{c}2.04 \pm 0.93 \\
(6)\end{array}$ & $\frac{3.82 \pm 1.56}{(4)}$ & $\frac{6.87 \pm 4.40}{(4)}$ & $\underset{(4)}{5.06 \pm 1.90}$ & $4.88 \pm 1.33$ \\
\hline
\end{tabular}

Each value represents the mean $\pm \mathrm{SD}$ and determined numbers was shown in parenthesis.

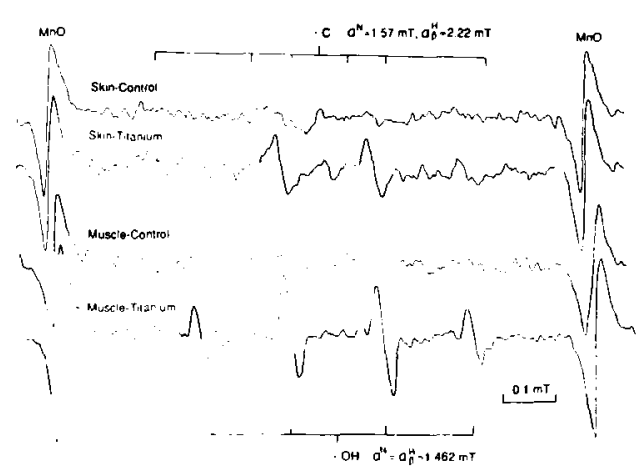

Fig. 1 Spectra of hydroxyl and carbon centered radicals as a spin adducts of 1,1 dimethyl-1-pyrroline- $\mathrm{N}$-oxide in the skin and muscle of rats one hour after implantation of titanium.

XG）を用いて・OH と・C をDMPO のスピ ンアダクトとして分析した. ESRスペクトロメ

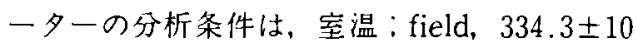
$\mathrm{mT}$; sweep time, 2 min ; modulation, 0.08 $\mathrm{mT}$; response, $0.1 \mathrm{sec} と し た{ }^{10}$.

フリーラジカル量は, 内部標集物質として使 用した酸化マンガンの信号強度と各フリーラジ カルの信号強度との比を求め，次いでこれと既 知スピン数の 2,2,6,6-tetramethyl-4-hydroxylpiperidine-1-oxyl (TEMPOL) の信号強度 とを比較計算してスピン数を求めた。
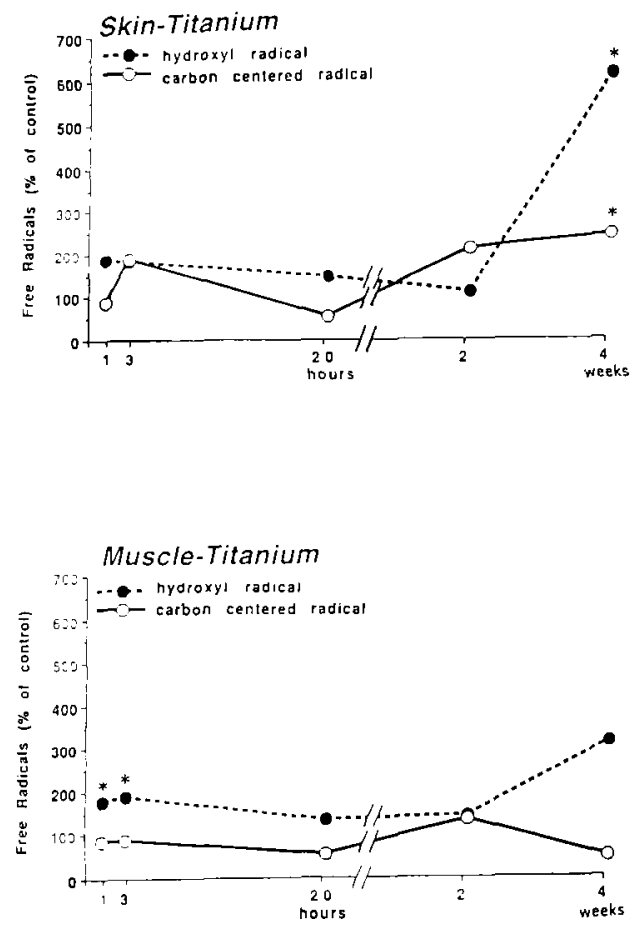

Fig. 2 Effect of titanium on hydroxyl and carbon centered radicals in the skin and muscle of rats. Each value represents the mean of 4-12 animals. " $p<0.05$ vs. shamoperated control group (Table 1).

\section{5 ，有意差検定}

有意差検定は上記の計算によって得られたス ピン数のオリジナルデーターについて Student's 
$t$-testを用いて行った.

\section{結果}

まず，対照（sham-operation）群について皮 虐組織と筋組織における・OH と・C の時間経 過による変動を調へた。その結果，皮膚組織に おいて 3 時間および20時間目に一過性に・ $\mathrm{OH}$ か 有意に増加する以外，全過程を通じてフリーラ ジカルの有意な変動は認められなかった(Table 1). 従って，以下の医用インプラント材原料の ペレットを埋め込んだ実験の成績は，上記の对 照値との比（\%）として表示した。

5 種類の医用インプラント材原料のペレット をラットの皮有および筋組織内に埋め込むと， 時間経過は異なるがいずれも皮虐ならびに筋肉 組織中に・OH と・C が発生することが ESR スペクトロメーターにより DMPO のスピンア
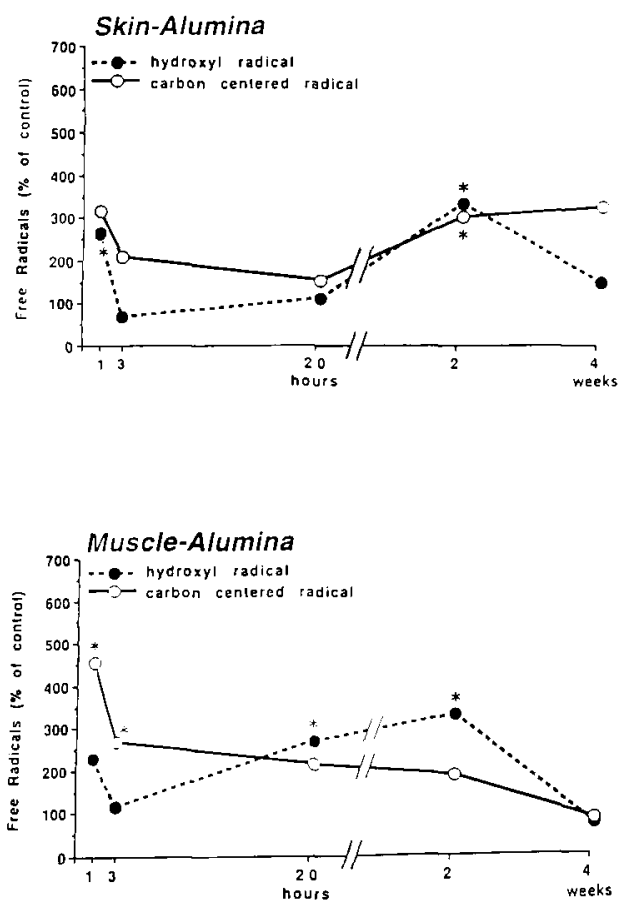

Fig. 3 Effect of alumina on hydroxyl and carbon centered radicals in the skin and muscle of rats. Each value represents the mean of 4-12 animals. " $p<0.05$ vs. shamoperated control group (Table 1).
ダクトとして検出された．Fig.1にチタン埋め 込み 1 時間目のスピンアダクトを代表例として 示した。

チタンを埋め込むと，皮度組織においては(Fig． 2 上段)， 2 週間目までは・ OH と・Cに有意な 変化は認められなかったが, 4 週間目には・ $\mathrm{OH}$ と・Cはいずれも有意に増加し，特に・ $\mathrm{OH} の$ 增加が顕著であった。他方，筋組織中の・ $\mathrm{OH}$ は 埋め込み $1 ， 3$ 時間目に有意に増加したが，20 時間目には対照レべルに回復した。なおその後 の変化には有意差は認められなかった。・Cは4 週間までに有意な変化を示さなかった（Fig. 2 下段).

アルミ十を埋め込むと（Fig．３），皮有の・ OH は 1 時間目に有意に増加したが，埋め込み 3 時 間目には対照しベルに回復した。ささらに埋め込 み 2 週間目には再び有意に増加したか，埋め込
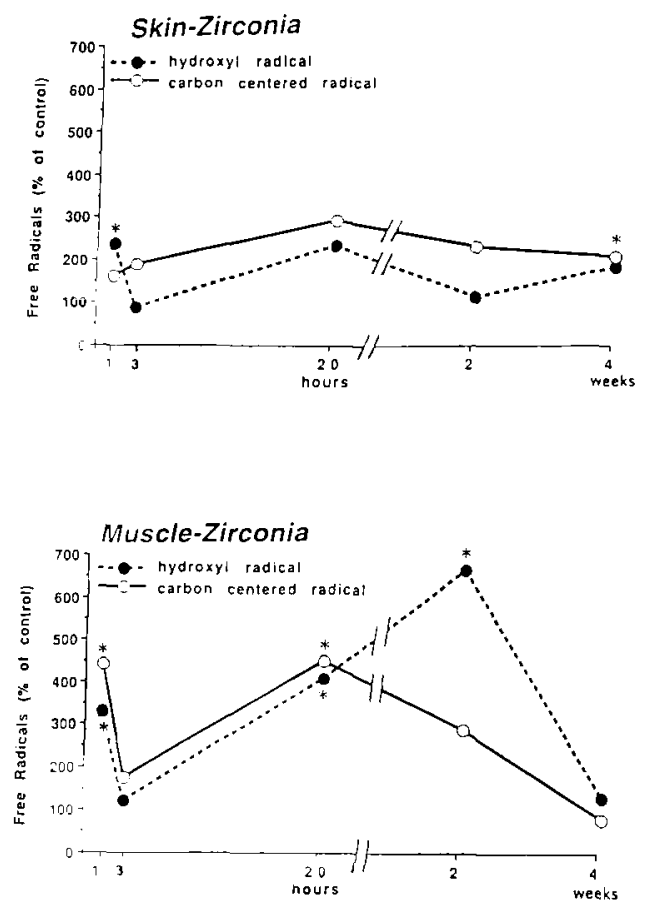

Fig. 4 Effect of zirconia on hydroxyl and carbon centered radicals in the skin and muscle of rats. Each value represents the mean of $4-12$ animals. ${ }^{*} p<0.05 v$ s. sham. operated control group (Table 1). 
み 4 週間目には対照レベルに回復した。C・は埋 め込み 1 時間目に增加する傾向が認められたが 有意ではなく，埋め込み2週間目には有意に増 加していた。しかし埋め込み 4 週間目には对照 レベルに回復した(Fig. 3 上段)。一方，筋組織 においては・OH は埋め込み20時間目に有意に 增加し、埋め込み 2 週間目にはさらに增加した。 しかし，埋め込み 4 週間目には対照レベルに回 復した。CCは埋め込み 1 時間目に著明に增加し， 埋め込み 3 時間目にはやや減少したものの，な お有意に增加していた。しかし埋め込み20時間 目以降 4 週間目までは对照レべルであった(Fig. 3 下段).

ジルコニアを埋め込むと（Fig．4)，埋め込み 1 時間目に皮䖉組織の・OH は有意に増加した が、埋め込み 3 時間目には対照レベルに回復し た. その後, 埋め込み 4 週間目まで多少の変動
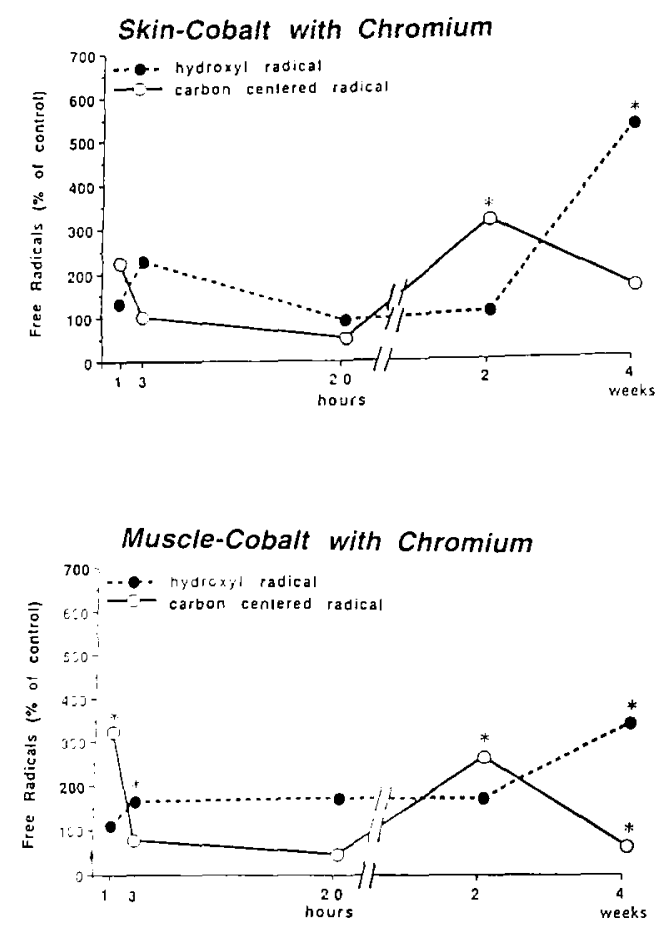

Fig. 5 Effect of cobalt with chromium on hydroxyl and carbon centered radicals in the skin and muscle of rats. Each value represents the mean of 4-12 animals. ${ }^{*} p<0.05 v s$. sham-operated control group (Table 1).

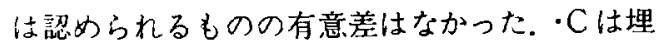
め込み後より増加の傾向が認められたが, 有意 差の認められたのは埋め込み 4 週間目のみであ った(Fig. 4 上段)。一方，筋組織においては(Fig. 4 下段)，埋め込み 1 時間目に・ $\mathrm{OH}$ と・C は 共に著明に增加したが，埋め込み 3 時間目には いずれも対照レベルに回復した，次いで，埋め 込み20時間目には両者のフリーラジカルは共に 再び有意に著明に增加し，さらに，埋込み 2 週間目には・OHはさらに増加したが,・Cは減 少した。しかし，埋め込み 4 週間目にはいずれ のフリーラジカルも对照レベルに回復した。

コバルトークロムの合金は, 皮虐組織において は・OH は埋め込み 2 週間後までは変化が認め られなかったが, 埋め込み 4 週間目には有意に 増加した (Fig. 5 上段)。一方，Cは埋め込み 2 週間目に有意に増加したが, 埋込み 4 週間
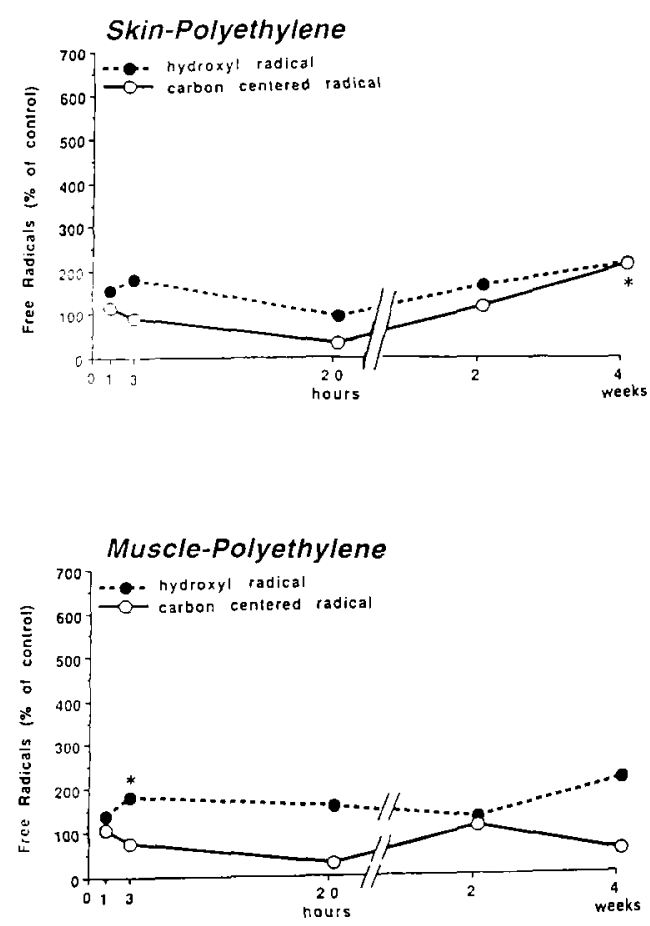

Fig. 6 Effect of polyethylene on hydroxyl and carbon centered radicals in the skin and muscle of rats. Each value represents the mean of $4-12$ animals. ${ }^{*} p<0.05 v s$ s. sham. operated control group (Table 1). 
目には減少した，筋組織においては（Fig.5下 段),・OH は埋め込み 3 時間目に有意に増加し た.その後レベルは一定值を保ち，埋め込み 4 週間目には著明に増加した。他方，・Cは埋め込 み 1 時間目に著明に増加したが埋め込み 3 時間 目には対照レベルに回復した。その後埋め込み 2 週間目には再び有意に増加したが，埋め込み せ週間目には減少し，逆に有意に対照レベルよ りも低下した。

超高分子ポリエチレンは, 皮膚組織中の・OH と・Cに埋め込み 1 時間目から埋め込み 2 週間 目まで若干の変動を与之たが有意差は認められ なかった(Fig. 6 上段)。しかし，埋め込み 4 週 間目の・Cは有意に增加していた。筋組織にお いては (Fig.6下段),・OH は埋め込み 3 時間 目に有意に増加したが，埋め込み20時間目から 埋め込み 4 週間目まで有意差は認められなかっ た。・Cには埋め込みによる有意な変化は認めら れなかった。

\section{考察}

一般に多くの金属すなわち、ナトリウム、マ グネシウム,カリウム、カルシウム、バナジウ ム, クロム, マンガン, 鉄, ニッケル, 銅, 亜 鉛，モリブデンおよび錫は動物にとっては必須 の金属である.しかし、これらの金属を過剩に 攝取すると細胞傷害を引き起こすことが知られ ており，生体に对する金属の影響については以 下のように多くの報告がある。例えばリノレイ ン酸やリノレニン酸などの不飽和脂肪酸の酸化 はコバルト（II），マンガン（II）により強く触 媒され，銅（II），鉄（IIおよびIII）によっても 促進される"1). 銅（II）、鉄（IIおよU゙III），鉛， 水銀，銀は溶血を引き起こし，赤血球膜の過酸 化を促進する ${ }^{22}$ ．銀，水銀，銅（II）および鉛は カタラーゼやグルタチオンペロキシダーゼを不 活化し，赤血球内の還元型グルタチオン量を低 下させる ${ }^{13)}$. 鉛, 鉄 (II )，銅（II），水銀，ク口 ム（III），マンガン（IV）またはセレン（II）を 腹腔内に投与寸ると，マウス肝䠞の過酸化脂質 は增加するが，セシウム(III)，マンガン (II)， コバルト（II）またはニッケル（II）は過酸化 を生じないという報告がなされている14)。また，
脳においてはコバルトやニッケルを毎日 7 日間 腹腔内投与するとラット脳の過酸化脂質は增加 し，スーパーォキシドジスムターゼ活性は低下 することが知られている(15,16).さらに,カリウム， コバルト (II)，カルシウム，二ッケル（II）， 銅（II），マグネシウム（II），鉄（III）およU゙ アルミニウムはラットシナプトゾーム分画から フリーラジカルを発生させ, 発生したフリーラ ジカルが膜の流動性を低下きせることが報告さ れている17). 最近, Wang らはコバルト (II) やニッヶル（II）は鉄（III）と同様に内在性ア スコルビン酸ラジカルを増加させることをラッ 卜体外循環中において認め，過剩の遷移金属を 椇取するとフリーラジカルが発生することを示 唆している ${ }^{18)}$.これらの知見は生体内に過剩に取 り込まれた金属がフリーラジカルの発生を惹起 し，生体内で過酸化反応を引き起こすことを示 している.

金属の関与する活性酸素生成反応において， 生体内で起こりうると考えられているものに， 下記のフェントン反応 ${ }^{19}$ がある。

$$
\mathrm{Fe}(\mathrm{II})+\mathrm{H}_{2} \mathrm{O}_{2} \rightarrow \mathrm{Fe} \text { (III) }+\cdot \mathrm{OH}
$$

最近細胞膜傷害にはフリーの・OHばかりで なく，遷移金属である銅，ニッケルおよU゙コバ ルトなどと $\mathrm{H}_{2} \mathrm{O}_{2}$ によって生成する金属と・OH との結合型が活性種であることが示されてい る ${ }^{4-71}$.また, マンガンは発癌性は認められてい ないが，変異原性を示すことが知られており， $\mathrm{H}_{2} \mathrm{O}_{2}$ を介さないで・ $\mathrm{OH}$ を発生することが知 られている8. 一般に・OH は膜の二重結合に作 用して水素を引き抜き，その結果アルキル基の フリーラジカルとなるが，今回測定したカーボ ンセンターラジカルの成績はそのような反応の 結果と考えられる。

本実験において，皮膚組織と筋組織にアルミ ナ, ジルコニア、チタン、コバルトークロム合金, 超高分子ポリエチレンの微粒子をぺレットとし て埋め込むと，埋込父後の急性期すなわち 1 ， 3 時間目にいずれかの組織あるいは両方の組織 で・OH が增加すること，さらには・Cについ てはアルミ十、ジルコニアおよびコバルトークロ 么合金によって增加することが明らかとなった。 ついで2 週間目に拈いてもアルミ十，ジルコニ 
ア、コバルトークロム合金によって・OH あるい は・Cが增加している場合があるが，4週間目 にはこれらは筋組織においてははとんど对照レ ベルに回復していた。この回復は生体内のフリ 一ラジカル消去作用を介しての防御機構による ものと想定される。しかしながら，4週間目の 皮虑組織においてはアルミナを除く 4 種の医用 材原料は・ $\mathrm{OH} や ・ C$ を增加させていること， および筋組織においてもコバルトークロム合金が ・OH を増加させていることなど，埋め込み後 長期にわたってフリーラジカルが発生すること が明らかになった。なお，皮膚組織と筋組織に おいては、これらのフリーラジカルの発現に相 違が認められたが, これは両組織中における抗 酸化活性すなわちフリーラジカル消去系の違い によるものと想定される。

以上の実験結果は人工関節などの摩滅によっ て生じる金属微粒子などに对する生体組織の反 応により，七ドロキシルラジカルが異常発生し て細胞・組織傷害が発生する可能性を示唆する ので，人工臓器などの開発に伴う素材原料の研 究は今後の重要な課題となるであろう。なお，

人工藏器装着により予想されるフリーラジカル 発生に对して、アスコルビン酸, $\alpha$-トコフェロ 一ル，グルタチオンなどのフリーラジカル消去 剤あるいは抗酸化戍を樍極的に摂取するような 防卸対策が考えられるので，その基礎的研究の 発展も期待される。

\section{結 論}

5 種類の医用インプラント材原料のペレット を皮嵓ならびに筋組織に埋め込み, ESR スペク トロメーターを用いて皮膚および筋組織中のフ リーラジカルを経時的に測定し，以下のことを 明らかにした。

1.チタンを埋め込むと皮膚組織中の・ $\mathrm{OH}$ と ・Cは埋め込み 4 週間目に增加した。筋組織中 の・ $\mathrm{OH}$ は埋め迟み 1 および 3 時間目に增加し たがその後回復した。

2、アルミ十を埋め込むと, 皮虞組織中の. $\mathrm{OH}$ は埋め込み1時間目に增加したがその後回 復した。しかし，埋め込み 2 週間目には・OH と ・Cは增加したが埋め込み 4 週間目には回復し
た. 筋組織中の・ $\mathrm{OH}$ は埋め込み20時間および 2 週間目には增加したが，埋め込み 4 週間目に は回復した。C泣埋め込み 1 および 3 時間目に 增加したが埋め込み20時間目には回復した。

3.ジルコニアを埋込むと, 皮虙組織中の ・OH は埋め込み 1 時間目に增加したが，その 後の有意な変化は認められなかった。筋組織中 の・ $\mathrm{OH}$ と・Cは埋め込み 1 時間目に増加した が埋め込み 3 時間目に減少した。埋め込み20時 間目より 2 週間目には・OH はさらに著明に增 加したが，4週間目には回復した。Cいは2週間 目には減少し，4週間後には回復した。

4.コバルトークロムの合金を埋め込むと、皮 虙組織中の・Cは 2 週間目に增加したが埋め込 み 4 週間目には回復した。また, $\mathrm{OH}$ は埋め込 み 4 週間目に著明に増加した、筋組織中の・ $\mathrm{OH}$ は埋込み 3 時間目に增加した後一定の值を保 ち、4週間目にはさらに增加した。・Cは埋め込 み 1 時間目に增加し， 3 時間目に回復したが, 20時間目に増加し，4 週間目に劇的に減少した。

5 ，超高分子のポリエチレンを埋め込むと皮 膚組織中の・Cは 4 週間目に増加した。筋組織 中の・OH は 3 時間目に増加したが，20時間目 には回復しな。

6. 以上より，医用インプラント材原料をぺ レットとして埋め込むと，皮膚および筋組織に おいては上記すべての材料により一過性にフリ 一ラジカルが発生すること，さらには・OHの 発生が埋め込み急性期ばかりでなく 4 週間後に おいても認められる場合のあることが明らかと なった。そして、これらの発生したフリーラジ カルが細胞・組織傷害の原因となることが示唆 された。

稿を終るに当り，御指導，御校閲を睗った森 昭 版教授に深甚なる謝意を表すと共に，直接御指導い ただきました平松 緑博士(現，山形県テクノポり 又財団生物ラジカル研究室）ならじに材料を供与下 さいました京セラ株式会社に感謝致します。

なお，本研究は平成 4 年度医療機器センタ一新医 撩技術開発研究事業の研究助成（主任研究者：森 昭片教授を頂いたことを記し感謝致します。 
女

1) Kawanishi S, Inoue $S$ and Sano $S:$ Mechanism of DNA cleavage induced by sodium chromate (VI) in the presence of hydrogen peroxide. J Biol Chem (1986) 261, 5952-5958.

2) Kawanishi $S$, Inoue $S$ and Yamamoto $K$ : Hydroxyl radical and singlet oxygen production and DNA damage induced by carcinogenic metal compounds and hydrogen peroxide. Biol Trace Elm Res (1989) 21, 367-372.

3) Inoue $\mathrm{S}$ and Kawanishi S : Hydroxyl radical production and human DNA damage induced by ferric nitrilotriacetate and hydrogen peroxide. Cancer Res (1987) 47, 6522-6527.

4) Yamamoto K, Inoue S, Yamazaki A, Yoshinaga $T$ and Kawanishi $S:$ Site-specific DNA damage induced by cobalt (II) ion and hydrogen peroxide : Role of singlet oxygen. Chem Res Toxicol (1989) 2. $234-239$.

5 ) Kawanishi S, Inoue S and Yamamoto K : Sitespecific DNA damage induced by nickel (II) ion in the presence of hydrogen peroxide. Carcinogenesis (1989) 10, 2231-2235.

6) Inoue $S$ and Kawanishi S : ESR evidence for superoxide, hydroxyl radicals and singlet oxygen produced from hydrogen peroxide and nickel (II) complex of glycylglycyl-L-histidine. Biochem Biophys Res Commun (1989) 159. 445-451.

7) Yamamoto $K$ and Kawanishi $S$ : Hydroxyl free radical is not the main active species in site-specific DNA damage induced by copper (II) ion and hydrogen peroxide. J Biol Chem (1989) 264, 1543515440.

8) Kawanishi S and Yamamoto $\mathrm{K}$ : Mechanism of site-specific DNA damage induced by methylhydrazines in the presence of copper (II) or manganese (III). Biochemistry (1991) 30, 3069-3075.

9) Yamamoto $\mathrm{K}$ and Kawanishi S : Site-specificc DNA damage by phenylhydrazine and phenelzinne in the presence of $\mathrm{Cu}$ (II) ion or Fe (III) complexes ; Role of active oxygen species and carbon radicals. Chem Res Toxicol (1992) 5, 440-446.

10) Hiramatsu M, Edamatsu R, Kohno $M$ and Mori $A$ : Scavenging of free radicals by Sho-saiko-to-gokeishi-ka-shakuyaku-to (TJ-960) $;$ in Recent Advances in the Pharmacology of Kampo (Japnese Herbal) Medicines, Hosoya E and Yamamura Y eds, Excerpta Medica, Tokyo (1988) pp 120-127.

11) Wills ED : Mechanisms of lipid peroxide formation in tissues. Role of metals and haematin Proteins in the catalysis of the oxidation of unsaturated fatty acids. Biochim Biophys Acta (1965) 98, 238251.

12) Ribarov SR and Benov LC : Relationship between the hemolytic action of heavy metals and lipid peroxidation. Biochim Biophys Acta (1981) 640, 721-726.

13) Ribarov S, Benov L, Benchev I, Monovich $O$ and Markova V : Hemolysis and peroxidation in heavy metal-treated erythrocytes: GSH content and activities of some protecting enzymes. Experientia (1982) 38, 1354-1355.

14) Schmid von $A$, Beuter $W$ and Friedrich $A$ : Lipid peroxidation in vivo durch Schwermetalle. Wien Tierarztl Monatsschr (1983) 70, 77-81.

15) Hasan M and Ali SF : Effects of thallium, nickel, and cobalt administration on the lipid peroxidation in different regions of the rat brain. Toxicol Appl Pharmacol (1981) 57, 8-13.

16) Ohtawa $M$, Seko $M$ and Takayama $F$ : Effect of alminium ingestion on lipid peroxidation in rats. Chem Pharm Bull (1983) 31, 1415-1418. 
17) Ohba S, Hiramatsu M, Edamatsu R, Mori I and Mori A : Metal ions affect neuronal membrane fluidity of rat cerebral cortex. Neurochem Res (1994) 19, 237-241.

18) Wang X, Yokoi I, Liu J and Mori A : Cobalt (II) and nickel (II) ions as promoters of free radicals in vivo : detected directly using electron spin resonance spectrometry in circulating blood in rats. Arch Biochem Biophys (1993) 306, 402-406.

19) Walling C : Fenton's reagent revisited. Accounts Chem Ress (1975) 8, 125-131. 


\title{
Free radical generation induced by prosthesis materials
} in the skin and muscle of rats Yumi Endo

\author{
Department of Neuroscience, Institute of Molecular and Cellular Medicine, \\ Okayama University Medical School, \\ Okayama 700, Japan \\ (Director : Prof. A. Mori)
}

The effect of pellets of prosthesis materials on free radicals were examined using electron spin resonance spectrometry. Pellets used were titanium, alumina, ziruconia, an alloy of cobalt with chromium and polyethylene. These pellets were implanted in the abdominal skin and thigh muscle tissue of rats. Animals were sacrificed by decapitation at 1, 3, 20 hours and 2 and 4 weeks after implantation and subcutaneous and muscle tissues were dissected. Hydroxyl radicals and carbon centerd radicals were analyzed as spin adducts of spin trap, 5, 5-dimethyl1-pyrroline- $\mathrm{N}$-oxide. Hydroxyl and carbon centered radicals in the skin and muscle tissues were increased 1-3 hours after the implantation of these materials and these changes were almost recovered to the normal level 20 hours after the implantation except for alumina and ziruconia in the muscle. However, hydroxyl radicals and/or carbon centered radicals were increased in the skin 4 weeks after the implantation of zirconia, titanium, an alloy of cobalt with chromium and polyetylene. These results suggest that the subacute stage after the implantation of particles of prostheseis materials into the skin and muscle tissues induces the generation of free radicals and then these free radicals may produce tissue damage. 